\title{
ÜVEGTÁBLÁK TERVEZÉSÉRE FELHASZNÁLT SZABVÁNYOK
}

\section{DESIGN CODES FOR GLASS SHEET DESIGN}

Vekov Imre

\author{
Kolozsvári Müszaki Egyetem, Épitömérnöki kar, 400020, Románia, Kolozsvár, \\ Constantin Daicoviciu utca, 15 szám; Telefon / Fax: +407382690, \\ wimrew@gmail.com
}

\begin{abstract}
Glass sheets are the basis of design for every glass structure. Numerous standards limit the use of glass as a structural material, and help in the calculation of glass sheets. Some of the most important design codes from the world are the German DIN18008, the American E1300-12a, the Canadian CAN/CGSB-12.20, and the Australian AS 1288-2006. The present work presents these design codes and offers a comparison for a better understanding of similarities and differences in glass sheet design.

Keywords: glass sheet, design codes, structure.

\section{Összefoglalás}

Az üvegszerkezetek tervezésének az alapját az üvegtáblák méretezése képezi. Több szabvány is használatos, amelyek megszabják az üvegtáblák felhasználásának feltételeit és segítséget nyújtanak a méretezésben. A világ talán legjelentősebb üvegtáblák tervezésére vonatkozó szabványai a német DIN18008, az amerikai E1300-12a, és az ausztrál AS 1288-2006. A dolgozat bemutatja ezen szabványokat, és párhuzamot von, hogy jobb átláthatóságot biztosítson az üvegtáblák tervezése terén felmerülő hasonlóságokban és különbségekben.
\end{abstract}

Kulcsszavak: üvegtábla, szabvány, szerkezet.

\section{Bevezetés}

Építőmérnöki tervezéskor mindig a célország szabványait kell figyelembe venni, ezért fontos ismerni a világban használatos, sokszor más szabványok összeállításánál irányt adó szabványokat, szakcikkeket. Az üveg a müépítészek által kedvelt szerkezeti anyag, amely egyre nagyobb mértékben kerül beépítésre világszerte. A magas nyomószilárdság, a kémiai hatásokra való ellenállás, az üveget az egyik legtartósabb építőanyaggá teszi. Az üveggel való tervezést különböző szabványok teszik lehetővé, melyek általában egy-egy ország területén belül szabályozzák az üveggel való tervezés feltételeit. A világon talán a három legismertebb üvegtervezés célját szolgáló szabvány a német DIN18008, az amerikai E1300-12a, és az ausztrál AS 1288-2006. A dolgozat ezen szabványokat helyezi egymás mellé, elsősorban üvegtáblák tervezését figyelembe véve.

$\mathrm{Az}$ üveg, mint építőanyag esetén a fö tervezési irányelvek nem változnak, csak a forma más néhány esetben. A szerkezeti üveg világában eligazodni vágyóknak fontos ismerniük úgy a hasonlóságokat, mint a különbségeket, hogy bármely 
tervezési környezet esetén könnyen eligazodhassanak.

\section{A német DIN18008}

A DIN18008 szabványban találhatjuk meg a német üvegszerkezetek tervezésre vonatkozó elöírásokat. Az első és a második alfejezet (Begriffe und allgemeine Grundlagen, valamint Linienförmig gelagerte Verglasungen) foglalkozik az üvegtáblák tervezésére vonatkozó elöírásokkal [1]. A szabvány elöírja a parciális biztonsági eljárás alapján történő számolást, ahol mind a teherbírási mind a használhatósági határállapotokat figyelembe kell venni. Az igénybevételek $\left(E_{d}\right)$ (esetünkben feszültségek), kisebbek kell legyenek mint a teherbírás $\left(R_{d}\right)$. $\mathrm{Az}$ üvegtáblák igénybevételeit a szabványban megnevezett források alapján lehet kiszámolni. Az üveg viselkedését, mint lineárisan rugalmas anyagot kell figyelembe venni. A szabvány meghatározza az értékét több a szóda-lime szilikát üvegre vonatkozó tulajdonságnak, úgy mint a rugalmassági modulusnak $\left(E=70000 \mathrm{~N} / \mathrm{mm}^{2}\right)$, a Poisson tényezőnek $(v=0.23)$, valamint a hőtágulási együtthatónak $\left(\alpha_{T}=9.0 * 10^{-6} / \mathrm{K}\right)$.

A szabvány 3-19 mm vastagságú üvegtáblákra vonatkozik, és tiltja azon üvegtáblák használatát, melyeken olyan sérülések találhatók, melyek mélyebbek a vastagság 15 százalékánál. Az üvegtábla helyzete alapján megkülönböztetésre kerülnek függőleges (dölésszög $\leq 10^{\circ}$ ) és vízszintes üvegtáblák (dőlésszög $>10^{\circ}$ ). Különböző képletekkel számolható az üvegtábla teherbírása, az üveg típusának függvényében. Edzett üvegtáblák esetén az (1)-es képlettel számolunk, míg nem hőkezelt üvegtábla esetén figyelembe vesszük a $k_{\text {mod }}$ tényezőt is és a módosított, (2)-es képlettel jutunk a helyes eredményhez.

$$
R_{d}=\frac{k_{c} * f_{k}}{\gamma_{M}}
$$

$$
R_{d}=\frac{k_{m o d^{*}} k_{C^{*}} f_{k}}{\gamma_{M}}
$$

A képletekben megtalálható $f_{k}$ tényező az üvegtábla karakterisztikus hajlítószilárdságát jelöli, a $k_{c}$ tényező pedig a szerkezet típusát veszi figyelembe, értéke pedig, más kikötés híján 1 . A $k_{\text {mod }}$ tényező a nem hőkezelt üvegtábláknak a terhelési időtartamra való érzékenységét veszi figyelembe, három időtartam kategóriában.

A $k_{\text {mod }}$ tényezőt a legrövidebb ideig tartó terhelésre kell meghatározni. A teherbírási határállapot minden kombinációját le kell ellenőrizni, hiszen a teherbírás és a $k_{m o d}$ tényező is változhat kombinációnként. Ennek egyik következménye, hogy nem mindig a legnagyobb igénybevétel lesz a mértékadó a tervezés szempontjából. Laminált üveg esetén a teherbírás 10\%-kal nő. Amennyiben edzetlen üvegtáblák szélei is terhelésnek vannak kitéve, a teherbírás az eredeti $80 \%$-ára csökken.

\section{Az amerikai E1300-12a}

Az amerikai E1300-12a az ASTM (American Society for Testing and Materials) által kiadott, külső üvegezésre felhasznált üvegtáblák teherbírására vonatkozó szabvány [2]. A szabvány eszközöket biztosít teherbírás és lehajlás számolására, függőleges és dőlt üvegtáblák esetén. 2, 3 vagy 4 oldalon megtámasztott üvegtáblát lehetséges számolni, valamint konzolt. A számoláshoz egyenletesen eloszló terheléseket kell feltételezni, amelyek összege (önsúly, hó, szél stb. összege) nem haladja meg a $15 \mathrm{kPa}$ értéket.

A szabvány által biztosított eredmények 8/1000-es törésbiztonságot biztosítanak. A számítási eredmények azt a feltételezést foglalják magukba, hogy a felhasznált üveg felületi sajátosságai megfelelnek egy olyan üvegnek, amely már több éve használatban van, éppen ezért pedig gyengébb, mint egy frissen gyártott üvegtábla. A szabvány számítási módszerei nem használhatók 
olyan üvegtáblákra, melyek utókezelése csökkentette a tábla teherbírását (homokfúvás stb.). Laminált üvegtáblák esetén csak PVB (polyvinyl butyral) vagy egyenértékü köztes réteg esetén lehet a szabványt felhasználni. A számolások alapját egy elméleti üvegtörési modell adja, melynek eredményei grafikonokban (NFL charts) vannak összefoglalva a gyors felhasználás érdekében. Ezek egy 3 másodpercen át ható egyenletesen eloszló terhelésre nyújtanak eredményt, 8/1000-es törésbiztonsággal, nem hőkezelt üvegtáblák esetén.

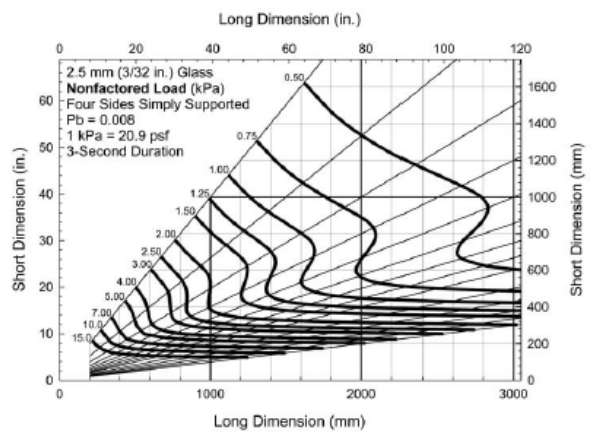

1. ábra. $2.5 \mathrm{~mm}$ vastag, 4 oldalon megtámasztott üvegtábla teherbirásának számolását elösegitö grafikon.

A tervezési folyamat során, a felhasználó, az üvegtábla méretei és a megtámasztás függvényében, kinyeri a grafikonokból a teherbírást. Ezt az eredményt szorozzuk be egy, az üveg típusát figyelembe vevő együtthatóval, valamint a terhelés hosszát figyelembe vevő együtthatóval, hogy megkapjuk a végső teherbírást. A terhelés és az üvegtábla méretei függvényében, a lehajlást is meg lehet határozni, ugyancsak grafikonok segítségével. A szabvány mellékletei tartalmaznak egy alternatív lehajlás vizsgálati módszert, tartalmazzák az igénybevétel hosszát figyelembe vevő tényezők meghatározását, különböző időtartamú igénybevételek kombinálását le- hetővé tevő módszert, valamint megközelítő maximum felületi feszültség számítást is.

\section{Az ausztrál AS 1288-2006}

Az ausztráliai AS 1288-2006 Glass in buildings-Selection and installation szabvány üvegtermékek kiválasztására és beszerelésére ad útmutatót, azon esetekre, ahol szélteherre vagy üvegfalnak ütköző emberi teherre történik a tervezés [3]. Az üveg teherbírása az üveg felületén lévő húzószilárdságon alapszik. Az (3)-as képlet az az alap összefüggés, melynek teljesülnie kell.

$$
S^{*} \leq \Phi R_{u}
$$

A képletben $S^{*}$ a rugalmas analízis során meghatározott igénybevételt, míg $\Phi R_{u}$ a végső teherbírást jelöli. A $\Phi$ együttható 0.67-nek tekinthető a számolás során, míg $R_{u}$-t a (4)-es képlet alapján lehet meghatározni.

$$
R_{u}=c_{1} * c_{2} * c_{3} * f_{t}^{\prime} * X
$$

A $c_{1}, c_{2}, c_{3}$ együtthatók az üveg típusát, az üveglap felületét, és az igénybevétel időtartamát veszik figyelembe. Az $f_{t}$ ' a karakterisztikus húzószilárdságot jelöli, és az üvegtábla szélén az (5)-ös, míg az üvegtábla belsejében a (6)-os összefüggéssel egyenlö, ahol az üvegtábla széle a tábla vastagságával megegyező szélességü sávot jelöli. Az $X$ egy geometriai együttható, mely az üvegtábla méretétől, alakjától és megtámasztásától függ.

$$
\begin{aligned}
& f_{t}^{\prime}=-7.88 * \ln (t)+57.07 M P a \\
& f_{t}^{\prime}=-9.85 * \ln (t)+71.34 M P a
\end{aligned}
$$

A szabvány a maximális lehajlást támaszköz/60 mértékben határozza meg 2, 3 vagy 4 oldalú megtámasztás esetén, valamint magasság/30-ban (hossz/30) konzolok esetén. Szélteherre való számolás esetén a szabvány feltételezi, hogy az igénybevétel rövidebb ideig tart mind 3 másodperc, és nem lépi túl a $10 \mathrm{kPa}$ értéket. Ezekre az esetekre a szabvány egyszerüsített képlete- 
ket és elöre megadott konstansokat biztosít a számítások gyorsítása végett. A szabvány 2 és 4 oldalon való megtámasztás között tesz különbséget, 3 oldalon való megtámasztás esetén kikötve, hogy 2 oldalú megtámasztásként kell számolni. Amennyiben az üvegtábla karcsúsága nagyobb mint 5 , ugyancsak 2 oldalú megtámasztással kell számolni.

\section{Következtetések}

Bár ez a dolgozat alapvetően a német, amerikai, és ausztrál üvegtervezésre szolgáló szabványokat vizsgálja, és világszinten ezek a leginkább alkalmazottak, fontos megemlíteni, hogy más országoknak (Franciaország, Olaszország, India stb.) is vannak hasonló szabványaik, de ugyanakkor, több ország nem rendelkezik még erre szolgáló szabványrendszerrel. Az európai szabványokat átfogó Eurocode rendszer 2020-ra tervezi az üveg Eurocode szabványrendszer kiadását.

A különböző országok szabványai között csak egy felületes összehasonlítás lehetséges, hiszen az alap-megközelítés legtöbb esetben különbözö, és az ország teljes szabványhátterének az ismerete szükséges egy átfogó kép nyújtásához. A német DIN18008 alapvetően a teherbírást határozza meg, függetlenül egy tényleges üvegtáblától, míg a két nem európai szabvány esetén a végső eredmény szorosan kötődik egy üvegtáblához, minimális táblavastagság, maximális támaszköz stb. meghatározása esetén.

Alapvetően több megközelítésbeli különbség figyelhető meg, ugyanakkor viszont néhány megegyező hasonlóság, vagy olyan különböző megkötések is megfigyelhetők, melyek azonos célt szolgálnak a szabványokban. Egy példa erre, hogy a szabványok általában valami- lyen formában figyelembe veszik, hogy az üvegtábla szélén több sérülés található, és sokszor ezek következtében történik meg a szerkezet tönkremenetele. A német DIN18008 80\%-ra csökkenti azon üvegtáblák teherbírását, ahol a tábla szélei is terhelésnek vannak kitéve, míg az ausztrál szabvány csökkentett teherbírást ír elő a tábla szélén lévő üvegsávon.

Minden szabvány figyelembe veszi az igénybevétel időtartamát, különböző időintervallumokkal és együtthatókkal. A német és a kanadai szabvány 3-3 igénybevétel időtartamot vesz figyelembe, míg az amerikai szabvány 11-et. A szabványok mindegyike figyelembe veszi a 2 és 4 oldalú megtámasztást, de csak az amerikai szabvány nyújt konzolok esetére számítási segédletet. Minden szabvány nagyjából azonos üvegtábla vastagságok esetén alkalmazható, 3 (2.5) mm és 19 mm közöttiekre. De ugyanakkor, csak az amerikai, a kanadai és az ausztrál szabványok nyújtanak grafikonokat és táblázatokat, hogy a mérnöki számításokat leegyszerüsítsék és felgyorsítsák.

\section{Köszönetnyilvánítás}

Köszönet illeti a "Collegium Talentum" intézetet a kutatási munkához nyújtott támogatásért, valamint Dr. Sandra Jordão-t és Dr. Aldina Santiago-t a kutatási munka során nyújtott segítségért.

\section{Szakirodalmi hivatkozások}

[1] DIN18008-1 Glass im BauwesenBemessungs- und Konstruktionsregeln, DIN Deutsches Institut für Normung, 2010, 1-8.

[2] E1300-12a, ASTM - American Society for Testing and Materials, 2009, 1-59 oldal.

[3] AS1288-2006 Glass in buildings-Selection and installation, Australian Standard, 2006, 1-142. 